(c) 2006 Blackwell Publishing, Inc.

\title{
Effect of water exchange on effluent and sediment characteristics and on partial nitrogen budget in semi-intensive shrimp ponds in New Caledonia
}

\author{
Hugues Lemonnier ${ }^{1 *}$ \& Sébastien Faninoz ${ }^{1}$
}

\author{
${ }^{1}$ Institut Français de Recherche pour l'Exploitation de la Mer, Département Aquaculture en Calédonie, Nouméa, \\ New Caledonia \\ Corresponding author : * hugues.lemonnier@ifremer.fr
}

\begin{abstract}
An experiment was conducted in six earthen ponds with 20 shrimps m2Litopenaeus stylirostris (Stimpson) during the warm season in New Caledonia to study the dynamics of wastes in relation with water exchange rate (WER). The nitrogen budget was established, taking into account the different forms of nitrogen in the water, sediment, feed and shrimp. Data from a wide range of treatments applied in unreplicated ponds were treated using regression analysis to establish the relationship between WER and partial nitrogen budget, sediment characteristics and shrimp performance. To compare effluent quality between treatments during the season, data were analysed using the nonparametric sign test. The water outflow was characterized by a decrease in the concentrations of $\mathrm{N}$ mineral forms (TAN, NO2-NO3), an increase in the concentration of organic soluble and sestonic organic forms (expressed in terms of particulate nitrogen, particulate organic carbon, chlorophyll a) compared with the water inflow. Increasing WER increased the amount of exported wastes and mainly in the organic forms and TAN can be considered as negligible. The nitrogen budget showed that 19$46 \%$ of nitrogen input (feed+water) was exported into the coastal environment. The results showed that the quality of the sediment decreased as WER decreased. The potential negative impact of the developing industry in New Caledonia on the costal environment could be partially reduced in a first step by decreasing WER. However, if applied in the farms, this practice should be linked to a close survey of the evolution of sediment quality.
\end{abstract}

Keywords: effluent, sediment quality, shrimp, water exchange, nitrogen, New Caledonia 


\section{Introduction}

Shrimp farming (Litopenaeus stylirostris Stimpson) in New Caledonia is a developing industry conducted in flow-through semi-intensive system, at 20-35 animals $\mathrm{m}^{-2}$ with an extrapolated yield ranging from 2.0 to $5.5 \mathrm{t} \mathrm{ha}^{-1} \mathrm{yr}^{-1}$. Seventeen operating farms covering 650 ha produced about 2, 000 tons in the 2003/2004 harvest season (Fonfreyde, Capo \& Guillaume 2004). As consequence of a seasonal pathology named "syndrome 93" which appears during the cold season, the industry produces essentially during the warm season (Harache \& Herbland 2004). With $400-\mathrm{km}$ coastline and the availability of coastal land that is not adequate for traditional agriculture activities, New Caledonia has a great potential to develop the shrimp industry. In 2007, it is envisaged to increase the production to about 5, 000 tons by increasing the number of ponds to reach in final an area of about 1300 ha (Fonfreyde et al. 2004).

Shrimp farms are built on the intertidal zone between mangroves and agricultural land with ponds integrated as much as possible to the natural landscape, inducing no mangrove wetlands destruction. The species cultured in New Caledonia is a non-indigenous species. The mexican blue shrimp Litopenaeus stylirostris was imported from the United States in 1980 from which almost 30 generations have been reared in captivity. The escapement of this species from farms could represent a significant concern. However, this shrimp has never been caught in the surrounding environment. The impact of shrimp farming on the coastal environment is mainly limited to aquaculture effluents (Lemonnier \& Herlin 1999). However, the multiplication of farms, the increase in production and the risk of intensification of the system may increase the pressure on the environment and could result in the long term to significant or insidious modifications in the lagoon, and possibly irreversible. The emergence of a new pathology in the last years named "summer syndrome", which has been localised until now in a single bay is another good reason to manage the environment, as the whole industry could be affected if the pathogen was spread via seawater (Harache \& Herbland 2004; Goarant, Ansquer, Herlin, Domalain, Imbert \& De Decker 2006). Thus, effluents should be monitored and managed to avoid or reduce any negative environmental impacts, to limit spreading of pathogenic microorganisms from seawater and to improve sustainability.

The decrease of water exchange rate (WER) has been studied throughout the world to limit the export of waste and to reduce the impact on coastal environment (Hopkins, Sandifer \& Browdy 1995; Sandifer \& Hopkins 1996; Martinez-Cordova, Porchas-Cornejo, VillarrealColmenares \& Calderon-Perez 1998). Water exchange (WE) is used to flush nutrients and phytoplankton from ponds to prevent excessive phytoplankton blooms. It removes toxic metabolic wastes such as ammonia, and dilutes pond water so that salinity does not become excessive. The major problem associated with the decrease of WER in semi-intensive system in earthen ponds is a rapid eutrophication of the system, resulting in increasing concentrations of nutrients and organic matter over the culture period. Nitrogen waste produced and oxygen drop could be ultimately making the environment toxic to shrimp.

Budgets are calculated including all nutrients gains and losses to quantify environmental impacts and to provide recommendations for farmers. The calculation of those budgets was established for experimental intensive shrimp ponds (Hopkins, Hamilton II, Sandifer, Browdy \& Stokes 1993), experimental semi-intensive shrimp ponds (Martin, Veran, Guelorget \& Pham 1998; Lemonnier, Martin, Brizard \& Herlin. 2003), commercial intensive shrimp ponds in Thailand (Briggs \& Funge-Smith 1994; Thakur \& Lin 2003), Australia (Jackson, Preston, Thompson \& Burford 2003), extensive shrimp ponds in Bangladesh (Wahab, Bergheim \& Braaten 2003), semi-intensive shrimp farms in Mexico (Paez-Osuna, Guerrero-Galvan, RuizFernandez \& Espinaza-Angulo 1997), Honduras (Teichert-Coddington, Martinez, Ramirez 2000) and Bangladesh (Islam, Sarker, Yamamoto, Wahab \& Tanaka 2004). However, the relationship between WER and the dynamics of wastes in marine shrimps needs to be fully investigated at semi-intensive level. 
The aim of the present study was double. First, it was to determine the effects of different WER on the nitrogen budget in semi-intensive shrimp rearing during the warm season. Second, it was to establish the relationship between WER, production parameters (survival, growth and yield) and the characteristics (nature and amount) of waste in effluent and pond sediment.

\section{MATERIALS AND METHODS}

\section{Pond management}

The experiment was carried out at the Caledonian Aquaculture Laboratory in 6 rectangular earthen ponds $\left(1500 \mathrm{~m}^{2}\right.$ surface area, mean water depth $\left.1.0 \mathrm{~m}\right)$ during the warm season (October 1998 to March 1999). Ponds were dried out for 10 days before filling. They were stocked with Litopenaeus stylirostris post-larvae at 20 shrimps $\mathrm{m}^{-2}$. Shrimp mean weight $(\mathrm{N}=100)$ was determined weekly. Shrimps were fed four times a day with a commercial feed (35-40\% protein, SICA, New Caledonia). Feeding rates were adjusted based on feed consumption, monitored with one feeding tray per pond, and biomass estimates calculated from weekly shrimp sampling. No fertilizer was added to the pond either before or during the experiment, and no aeration was used. Shrimps were harvested the same day in all ponds after 143 days of rearing.

Partial WE was performed daily in the morning. Water was pumped directly from the sea through a short supply canal $(50 \mathrm{~m})$ and introduced directly into the ponds by gravity via a short tube (diameter: $15 \mathrm{~cm}$ ). Flow rate for each pond was measured with a Mebflügel Meter (Type C2"10.150") several times during the experiment. WER was estimated taking into account the water flow for each pond and duration of WE. The beginning of the WE was synchronous for all ponds. Closing was shifted in time for the different ponds. The overall mean water inflow rates were $6 \%, 11 \%, 16 \%, 21 \%, 29 \%$ and $33 \%$ per day for respectively ponds 1,2 , 3, 4, 5 and 6.

\section{Water parameters}

Dissolved Oxygen (DO) and temperature were recorded daily (06:00 and 16:00 hours) at mid-depth near the discharge gate with a portable oxygen meter. Salinity and $\mathrm{pH}$ were measured twice a week in the evening (16:00 hours), using respectively a refractometer and a laboratory pH-meter.

Intake water samples were collected twice a week in the supply canal where water entered in ponds. Effluent samples were collected twice a week in all ponds at the discharges gates during the WE. Sampled water $(500 \mathrm{ml})$ was immediately filtered through a GF/C Whatman filter. Analysis included total ammonia nitrogen (TAN) (Koroleff 1976), nitrite and nitrate nitrogen $\left(\mathrm{NO}_{3}{ }^{-}+\mathrm{NO}_{2}{ }^{-}\right)-\mathrm{N}$ (Wood, Armstong \& Richards 1967) and total soluble nitrogen after mineralization (Raimbault, Pouvesle, Diaz, Garcia \& Sempéré 1999). To estimate Chlorophyll a (chl $a$ ), water samples of $25 \mathrm{ml}$ were filtered through GF/C Whatman filters and analysed by the fluorometric method (Holm-Hansen, Lorenzen, Holmes \& Strickland 1965). Total particulate nitrogen was determined on a Nitrogen-Carbon Analyser (Carlo-Erba 1500, Limito, Italy) (Hedges \& Sternes 1984). Suspended solids were measured for total particulate matter by drying at $60^{\circ} \mathrm{C}$ for $24 \mathrm{~h}$, and mineral matter (MM) and organic matter content by loss on ignition at $450^{\circ} \mathrm{C}$ after $4 \mathrm{~h}$.

\section{Sediment parameters}

Five sediment stations marked with graduated posts were studied in each pond at the beginning (day 1) and at the end (day 142) of the rearing period. The height of sediment accumulated on top of the original level was measured with a ruler for each station. This accumulation corresponded to the difference between the level observed at the beginning and at the end of the rearing. The redox potential $\left(\mathrm{E}_{\mathrm{h}}\right)$ was assessed in situ on the first centimetre using a specific electrode (Cofralab PT5700A; Schott Instruments, Mainz, Germany) according to the method described by Hussenot \& Martin (1995). pH of pore water was measured directly in the first 
centimetre with a $\mathrm{pH}$ meter (Hussenot \& Martin 1995). The two first centimetre layer of sediment was collected at each station using a PVC tube of $10 \mathrm{~cm}$ diameter. One hundred grams of each sediment sampled were centrifuged at $2000 \mathrm{~g}$ for 30 minutes. The supernatant (pore water) was analysed as previously described for water samples for TAN. Fifty grams were dried for 5 days at $60^{\circ} \mathrm{C}$ to calculate water content. Analysis of total nitrogen in dry sediments was carried out with the technique used for measurement of particulate nitrogen in water.

\section{Nitrogen budget}

In order to find out the main forms of nitrogen in the outflow in relation with the WER, amounts of particulate and soluble elements in the inflow and outflow were calculated. Daily concentrations were multiplied by exchanged water volumes to get the total mass of each parameter. Values for each parameter were integrated between two samplings and summed up for the season. Results were expressed in terms of pond surface area $\left(\mathrm{g} \mathrm{m}^{-2}\right)$. Balance net discharge refers to the difference between the outgoing and incoming amount for each parameter (Cho, Hynes, Wood \& Yoshida 1994). Nitrogen accumulation in the sediment was estimated by the difference between the nitrogen concentrations at the end of the experiment with concentrations at the beginning, taking into account the volume of the two first centimetres and the mean water content of the sediment. The nitrogen concentrations in feed pellets and in shrimp were determined in 10 samples and values were averaged.

\section{Statistical analysis}

Descriptive statistics of the pond, intake and effluent water quality are presented as mean, standard deviation of the mean, minimum (min), maximum (max). Regression analysis was carried out to determine the relationship between WER and (1) shrimp performance indices, (2) amount of particulate and soluble element input and output in the outflow, (3) sediment quality, and (4) accumulation of $\mathrm{N}$-wastes. Values were considered significant at $5 \%$ level of confidence. Survival rates were arcsin transformed prior to statistical analysis. Differences between inflowing and outflowing water quality for each pond, and outflowing waters between all ponds, were assessed using a distribution - free statistics named sign test (Scherrer 1984).

\section{RESULTS}

\section{Production results}

Shrimp mean weight at harvest increased significantly with increasing WER $\left(r^{2}=0.72\right.$; $\mathrm{P}<0.05$ ) (Table 1). Survival rates were higher than 70\% whatever the pond and the WER (Table 1) and seemed to decrease as WER increased. However it was not significant $\left(r^{2}=0.62\right.$; $\mathrm{P}=0.06$ ). Production ranged between 6.7 and $7.2 \mathrm{t} \mathrm{ha}^{-1}$ year $^{-1}$. Feed conversion ratio (FCR) was above 2.2 whatever the pond. Production, final biomass and FCR were not affecting by WER (Table 1).

\section{Water parameters}

Temperature did not differ between ponds and ranged from 23.9 to $30^{\circ} \mathrm{C}$ in the morning, and from 26.0 to $33.4^{\circ} \mathrm{C}$ in the afternoon. For all ponds, morning oxygen declined throughout the experiment from above $8 \mathrm{mg} \mathrm{L}^{-1}$ at the beginning to $2 \mathrm{mg} \mathrm{L}^{-1}$ at the end. Salinity values were $35-40 \%$ at the beginning of the experiment and below $25 \%$ ot the end (Table2).

Results of the sign test (Table 4) showed a decrease in the concentration of N-mineral forms, an increase in the concentration of organic soluble forms and in the sestonic forms (expressed in terms of particulate organic matter, particulate nitrogen, chl-a) between inflow and outflow waters (Table 3). Mean total nitrogen concentration in the inflow was $0.20 \pm 0.05 \mathrm{mg} \mathrm{L}^{-1}$ and values ranged between 0.13 to $0.37 \mathrm{mg} \mathrm{L}^{-1}$. The mean concentrations in the outflow ranged from $0.52 \pm 0.21$ to $0.95 \pm 0.40 \mathrm{mg} \mathrm{L}^{-1}$.

Concentrations of particulate nitrogen (Fig. 1), particulate organic matter, chl $a$ and organic soluble nitrogen in outflow (Fig. 2) water decreased as WER increased (Table 4). Regardless of WER, $58 \%$ to $63 \%$ of total nitrogen was particulate nitrogen. Concentrations of 
seston, mineral matter, TAN and $\left(\mathrm{NO}_{2}{ }^{-}+\mathrm{NO}_{3}{ }^{-}\right)-\mathrm{N}$ in different outflows were not or rarely different between treatment $(\mathrm{P}>0.05)$. Concentrations of mineral soluble nitrogen in effluent (Table 3) were low: mean $\left(\mathrm{NO}_{2}{ }^{-}+\mathrm{NO}_{3}{ }^{-}\right)-\mathrm{N}$ was less than $1.13 \mu \mathrm{g} \mathrm{\textrm {L } ^ { - 1 }}$, and mean TAN less than $20.7 \mu \mathrm{g} \mathrm{L}^{-1}$. The regression of particulate nitrogen against chl-a was significant $\left(\mathrm{r}^{2}=0.85 ; \mathrm{P}<\right.$ $0.001)$ with the equation chl-a $\left(\mu \mathrm{g} \mathrm{L}^{-1}\right)=9.8 \times$ particulate $\mathrm{N}\left(\mu \mathrm{g} \mathrm{L}^{-1}\right)+224.8$.

\section{Mineral matter and Nitrogen exported in effluents}

Nitrogen balance net discharge is shown in Fig. 3. It refers to the difference between the outgoing and incoming amounts for each parameter. An increase of the net discharge for total nitrogen, particulate nitrogen, organic soluble nitrogen with increasing WER was observed. However, net discharge of particulate nitrogen increased more rapidly than that of soluble organic nitrogen; 36 and 34\% of total nitrogen was discharged as organic soluble nitrogen for the two ponds with the lowest WER, while this ratio ranged from 27 to $29 \%$ for the other ponds. The balances of net discharge for mineral nitrogen were negative whatever the pond and decreased with increasing WER $\left(\mathrm{r}^{2}=0.96\right)$. The linear regression of mineral matter $\left(\mathrm{MM}\left(\mathrm{g} \mathrm{m}^{-2}\right)\right.$ $=-69+10 \times$ WER; $\left.\mathrm{P}=0.01, \mathrm{r}^{2}=0.80\right)$.) against WER indicates that these two parameters were closely related. The balance of MM was equal to 0 when WER was $7 \%$.

\section{Sediment parameters}

At the end of the rearing, mean $\mathrm{pH}$ did not differ between ponds and ranged from 7.0 to 7.1. Mean Potential redox ranged between $119 \pm 45 \mathrm{mV}$ to $144 \pm 21 \mathrm{mV}$ and water content between $45 \pm 13 \%$ to $59 \pm 8 \%$. Mean TAN decreased $(\mathrm{P}<0.05)$ as WER increased from 2.6 \pm 1.2 to $7.3 \pm 2.2 \mathrm{mg} \mathrm{L}^{-1}$. Mean $\left(\mathrm{NO}_{2}^{-}+\mathrm{NO}_{3}{ }^{-}\right)-\mathrm{N}$ ranged from $2.7 \pm 1.5$ to $4.9 \pm 1.4 \mu \mathrm{g} \mathrm{L}{ }^{-1}$. Total nitrogen concentration in the sediment ranged between $1.51 \pm 0.41 \mathrm{mg} \mathrm{g}^{-1}$ (pond 6) to $2.27 \pm 0.39 \mathrm{mg} \mathrm{g}^{-1}$ (pond 1). The height of sediment accumulated and the evolution of sediment characteristics are presented in Table 5. Accumulated layer, $\Delta \mathrm{pH}$ and $\Delta\left(\mathrm{NO}_{2}{ }^{-}+\mathrm{NO}_{3}{ }^{-}\right)-\mathrm{N}$ in pore water were similar whatever the pond studied. $\Delta$ Water content and $\Delta$ TAN increased as WER decreased (respectively $\mathrm{r}^{2}=0.76 ; \mathrm{P}=0.02$ and $\mathrm{r}^{2}=0.90 ; \mathrm{P}<0.01$ ).). $\Delta$ Redox potential decreased as WER increased $\left(r^{2}=0.93 ; P<0.01\right)$. Gain of nitrogen over the culture period ranged from 0.23 to 1.00 $\mathrm{mg} \mathrm{g}^{-1}$ dry weight and was not significantly correlated with WER $(\mathrm{P}=0.08)$.

\section{Nitrogen budget}

Nitrogen budget values are presented in Table 6. The nitrogen concentration in feed pellets and shrimp were $70.1 \pm 1.1$ and $32.2 \pm 4.6 \mathrm{mg} \mathrm{g}^{-1}$. The waste exported by effluent increased as WER increased and represented 19 to $46 \%$ of the total nitrogen input in the pond (feed and water). These budgets indicated that shrimp converted between 17 to $20 \%$ of the nitrogen gained through feed and water to tissue, and $20-21 \%$ of the nitrogen added as feed. The nitrogen waste accumulated in sediment during rearing ranged from 3.8 to $10.9 \mathrm{~g} \mathrm{~m}^{-2}$, counting for $7-26 \%$ of the total nitrogen input. The proportion of nitrogen imported through water and feed that was not found back when assessing budgets, was classified as "other". Values of "other" ranged from 11.5 to $17.1 \mathrm{~g} \mathrm{~m}^{-2}$ and corresponded to a loss of 81 to $120 \mathrm{mg} \mathrm{m}^{-2}$ of nitrogen day ${ }^{-1}$.

\section{DISCUSSION}

Ponds management studies usually are restricted by availability of ponds, forcing researchers to limit treatments to maintain adequate replicates for statistical analysis. A more appropriate means of obtaining information could be to conduct trials with single or duplicate ponds for each treatment over a wide range of treatment and analyze the data using regression analysis (Wudtisin \& Boyd 2005). A non-parametric test is possibly the best way to analyse temporal series presenting non-normal distribution, like data obtained in our experiment. The statistical test used to compare effluents between ponds and with the inflow water is based on the difference analysis between each data pair (Scherrer 1984).

The usual rule in terms of daily WER in New Caledonia is an increase from $5 \%$ at the beginning of the rearing to about $30 \%$ at the end (Aquacop 1984). This practice is water and 
energy consuming, as water is pumped. In this experiment, yield was the same whatever the WER suggesting the feasibility of a reduced WER leading to reduced energy costs for the industry as previously shown by Hopkins et al. (1993) and Martinez-Cordova et al. (1998).

Dissolved oxygen is the most critical water quality parameter in aquaculture, controlling survival and growth of shrimp in ponds (Boyd 1990). At the end of the experiment, minimum DO concentrations were below the required concentrations in all ponds. The values below $2 \mathrm{mg}$ $\mathrm{L}^{-1}$ can be considered as critical for the growth of the shrimps (Allan \& Maguire 1991). A reduced WER will not lead to low oxygen level in the pond. The pond water should be oxygenated or shrimps partially caught to decrease biomass in ponds as practiced in semiintensive shrimp farms in New Caledonia. Except for oxygen, the observed variations in studied water quality parameters were within the acceptable range for Litopenaeus stylirostris (Aquacop 1984).

Bottom soil quality has long been recognised as a factor influencing water quality and aquatic animal production (Boyd 1990). Reduced feeding, slower growth (Avnimelech \& Zohar 1986), low survival (Hopkins, Sandifer \& Browdy 1994) and possibly higher sensitivity to disease are reported in relation with deterioration of the pond bottom (Avnimelech \& Ritvo 2003). In this work, reduce WER decreases the waste exported to coastal environment. A negative effect on the sediment is characterized by TAN accumulation and decreasing of Redox. The results in this study shows an increase of water content as WER decreases, suggesting in a same time an increase of organic matter in pond sediment. (Avnimelech, Ritvo, Meijer \& Kochba 2001). It seems also that nitrogen accumulates in sediment while WER decreased, but the regression is not significant $(\mathrm{P}=0.08)$. Even if it is potentially feasible to reduce WER, if applied in the farms, this practice should be linked to a close survey of the evolution of sediment quality.

The impact of aquaculture effluents can vary considerably depending on the water quality supply in the ponds and the flushing rates of receiving water body. Oligotrophy of the water in the Caledonian lagoon is marked because of the influence of oceanic oligotrophic water inflow (Bujan, Grenz, Fischez \& Douillet 2000). Increased nutrient inputs in the lagoon could have a significant effect on lagoon water quality, especially at the back of the bays where shrimp farm effluents are mainly discharged. Water exchange resulted in a change of water characteristics between inflow and outflow and a net discharge of organic matter as indicated by a net discharge of organic soluble nitrogen and particulate nitrogen. Primary production could absorb intake inorganic nitrogen and could explain the negative discharge net balance. Primary productivity is a classical pathway to remove mineral nutrients from water, and helps pond digestion processes and lead to a reduction of mineral nitrogen pollutants in the discharge (Hopkins et al. 1993; 1995). Compared to concentrations in inflow, Ziemann, Walsh, Saphore \& Fulton-Bennet (1992) measured an increase of total N and TAN and a decrease of nitrate in the effluent from freshwater fish and prawn ponds and marine fish and shrimp ponds. The present study did not show an increase of TAN in effluent compared to concentration in inflow. DON form represents $75 \%$ of the soluble nitrogen in the Inflow and more than $94 \%$ in effluent. Soluble nitrogen is the main nitrogen source in the inflow (58\%) even though particulate nitrogen was the major $\mathrm{N}$ components of the effluents (58-63\%). The water outflow was characterized by an increase in the concentration of organic soluble forms and the sestonic organic forms (expressed in terms of particulate nitrogen, particulate organic carbon, chl $a$ ) compared to the water inflow.

Mean total nitrogen concentration in effluent ranged from 0.51 to $0.96 \mathrm{mg} \mathrm{L}^{-1}$ (soluble + particulate) and decreased as WER increased. The concentration was lower than values measured in Australia (Jackson et al. 2003; Jackson, Preston \&, Thompson 2004) whatever the WER. For intensive shrimp farms, typical net load of total nitrogen is around $1 \mathrm{~kg} \mathrm{ha}^{-1} \mathrm{day}^{-1}$. In this study, range of net load varied between 0.46 and $1.01 \mathrm{~kg}^{-\mathrm{ha}^{-1}}$.day ${ }^{-1}$. Net load for the highest WER was similar as the one observed in Australia for intensive system. Several works have shown that $27-57 \%$ of the nitrogen added to ponds is discharged (Funge-Smith \& Briggs 1998) and that this amount increases with density (Martin et al. 1998). In the present study 19 to $46 \%$ of the nitrogen added to ponds (water + feed) were flushed out of the ponds. The amount 
decreased as WER decreased. Despite TAN is generally considered as a major form (Lorenzen, Struve \& Cowan 1997, Jackson et al. 2003), it could be considered as negligible in this study. Mineral nitrogen (TAN $+\mathrm{N}^{-\mathrm{NO}_{2}}{ }^{-}+\mathrm{N}^{-\mathrm{NO}_{3}}{ }^{-}$) represents only 1 to $2.6 \%$ of total nitrogen even though it is established that ammonium is the main excretory product from shrimp (Burford \& Williams 2001). The ratio DON / total $\mathrm{N}$ ranged between 37 and $42 \%$ and was similar to the results found in Australia for intensive system (Jackson et al. 2003). DON proves to be an important source of wastes which concentration is closely linked to the WER. DON appeared to be produced principally from leaching of shrimp feed and faeces (Burford \& Williams 2001). Effluent is also characterized by high concentrations of particulate nitrogen and chl $a$. The significant regression of particulate nitrogen against chl $a$ indicates that these two parameters are closely related.

The percent of input $\mathrm{N}$ converted to harvested shrimp has important implications for water quality and profitability of pond aquaculture. Results indicate that about $20-21 \%$ of $\mathrm{N}$ added as feed is recovered in shrimps whatever the WER. The percentage in the present study was similar to the results obtained in intensive system in Thailand (Briggs \& Funge-Smith 1994) and in Australia (Jackson et al. 2003). Our study shows that water management and different eutrophication levels of the pond ecosystem had no effect on nitrogen assimilation by shrimp whereas natural biota can contribute significantly to shrimp nutrition (Burford, Jackson \& Preston 2001). These results suggest that WER could have no effect on the natural biota which contributes to the nutrition of shrimp. Others ways should be explored to significantly improve nitrogen assimilation and to reduce the environmental impacts of shrimp farming. At the animal level, improvements of feed formulations coupled with genetic selection for feed conversion efficiency should result in significant cumulative improvements to the reduction of N waste (Lawrence, Castille, Samocha \& Velasco 2001). At the pond level, an improved ability to adapt feeding strategies to seasonal and diurnal rhythms in feeding activity has also produced gains for aquaculturists (Burford et al. 2001).

For the highest WER, unrecorded nitrogen was estimated to count for 22 to $24 \%$ of total nitrogen input. For intermediate WER, the values ranged between 26 and 29\%. For the lowest WER, unrecorded nitrogen was highest and corresponded to $36 \%$ of total nitrogen input (water and sediment). Unrecorded nitrogen ranged from 11.1 to $15.2 \mathrm{~g} \mathrm{~m}^{-2}$ for all ponds which corresponds to a nitrogen loss between 78 and $106 \mathrm{mg} \cdot \mathrm{m}^{-2} \mathrm{~d}^{-1}$. These losses are attributed to a release in the atmosphere through denitrification and diffusion process (Hopkins et al. 1993, Briggs \& Funge-Smith 1994; Jackson et al. 2003).

\section{ACKNOWLEDGMENTS}

This work was supported by a research grant from the Northern Province, Southern Province and Institut Français de Recherche et d'Exploitation de la Mer (IFREMER). We gratefully acknowledge the comments and suggestions of referees on data analyses, and improving the style of the manuscript. We also want to thank L. Della Patrona, P. Brun, C. Lambert and E. Pita who kindly helped for the management of the ponds.

\section{REFERENCES}

Allan G.L. \& Maguire G.B. (1991) Lethal levels of low dissolved oxygen and effects of shortterm oxygen stress on subsequent growth of juvenile Penaeus monodon.. Aquaculture 94, 27-37.

Aquacop (1984) Review of ten years of experimental penaeid shrimp culture in Tahiti and New Caledonia (South Pacific). Journal of the World Mariculture Society 15, 73-91.

Avnimelech Y. \& Zohar G. (1986) The effect of local anaerobic conditions on growth retardation in aquaculture system. Aquaculture 58, 167-174.

Avnimelech Y., Ritvo G., Meijer L.E. \& Kochba M. (2001) Water content, organic carbon and dry bulk density in flooded sediments. Aquacultural Engineering 25, 25-33. 
Avnimelech Y. \& Ritvo G. (2003) Shrimp and fish pond soils: processes and management. Aquaculture 220, 549-567.

Boyd C.E. (1990) Water quality in ponds for Aquaculture. Alabama Agricultural Experiment Station. Auburn University, Alabama, USA, 482 pp.

Briggs M.R.P. \& Funge-Smith S.J. (1994) A nutrient budget of some intensive marine shrimp pond in Thailand. Aquaculture and Fisheries Management 25, 789-811.

Bujan S., Grenz C., Fischez R. \& Douillet P. (2000) Evolution saisonnière du cycle biogéochimique dans le lagon sud-ouest de Nouvelle-Calédonie. Application d'un modèle compartimental. Comptes Rendus de l'Académie des Sciences, Paris, 323, 225-233.

Burford M.A. \& Williams K.C. (2001) The fate of nitrogenous waste from shrimp feeding. Aquaculture 198, 79-93.

Burford M.A., Jackson C.J. \& Preston N.P. (2001) Reducing nitrogen waste from shrimp farming: an integrated approch. In:, The new wave. Proceedings of the Special Session on Sustainable Shrimp Culture, Aquaculture 2001 (ed. by C.L. Browdy \& D.E. Jory), pp. 35-43. The World Aquaculture Society, Baton Rouge, Louisiana, USA.

Cho C.Y., Hynes J.D., Wood K.R. \& Yoshida H.K. (1994) Development of high-nutrient-dense, low-pollution diets and prediction of aquaculture wastes using biological approaches. Aquaculture 124, 293-305.

Fonfreyde C., Capo S. \& Guillaume M. (2004) La filière crevette en Nouvelle Calédonie: situation actuelle, développement et besoins de recherche. In : Styli 2003. Trente ans de crevetticulture en Nouvelle Calédonie. Nouméa-Koné, 2-6 juin 2003. (Ed. by IFREMER), Actes Colloq., 38, 13-17.

Funge-Smith S.J. \& Briggs M.R.P. (1998) Nutrients budgets in intensive shrimp ponds: implication for sustainability. Aquaculture 164, 117-133.

Goarant C., Reynaud Y., Ansquer D., de Decker S., Saulnier D., Le Roux F. (2006) Molecular epidemiology of Vibrio nigripulchritudo, a pathogen of cultured penaeid shrimp (Litopenaeus stylirostris) in New Caledonia. Systematic and Applied Microbiology. In Press. Available online 18 January 2006.

Harache Y. \& Herbland A. (2004) Le programme Désans (Défi Santé Stylirostris) : une démarche comparable au défi Morest appliqué à la filière crevette calédonienne. In : Styli 2003. Trente ans de crevetticulture en Nouvelle Calédonie. Nouméa-Koné, 2-6 juin 2003. (Ed. by IFREMER), Actes Colloq., 38, 31-39.

Hedges J.I. \& Stern J.H. (1984) Carbon and nitrogen determinations of carbonate-containing solids. Limnology and Oceanography 29, 657-663.

Holm-Hansen O., Lorenzen C.J., Holmes P.E. \& Strickland J.D.H. (1965) Fluorometric determination of chlorophyll. Journal du conseil international pour l'exploitation de la mer 30, 3-15.

Hopkins J.S., Hamilton II R.D., Sandifer P.A., Browdy C.L \& A.D. Stokes (1993) Effects of water exchange rate on production, water quality, effluent characteristics and nitrogen budgets of intensive shrimp ponds. Journal of the World Aquaculture Society 24(3), 304320.

Hopkins J.S., Sandifer P.A. \& Browdy C.L. (1994) Sludge management in intensive pond culture of shrimp: effect of management regime on water quality, sludge characteristic, nitrogen extinction, and shrimp production. Aquacultural Engineering 13, 11-30.

Hopkins J. S., Sandifer, P.A. \& Browdy, C.L. (1995) A review of water management regimes which abate the environmental impacts of shrimp farming. In: Proceedings of the Special Session on Shrimp Farming (ed. by C.L. Browdy \& J.S. Hopkins), pp. 157-166. World Aquaculture Society, Baton Rouge, Louisiana, USA.

Hussenot J. \& Martin J.L.M., (1995) Assessment of the quality of pond sediment in aquaculture using simple, rapid techniques. Aquaculture International 3, 123-133.

Islam M.d.S., Sarker M.d.J., Yamamoto T., Wahab M.d.A. \& Tanaka M. (2004) Water and sediment quality, partial mass budget and effluent $\mathrm{N}$ loading in coastal brackishwater shrimp farms in Bangladesh. Marine Pollution Bulletin 48, 471-485. 
Jackson C.J., Preston N., Thompson P.J. \& Burford M.A. (2003) Nitrogen budget and effluent nitrogen components at an intensive shrimp farm. Aquaculture 218, 397-411.

Jackson C.J., PrestonN. \& Thompson P.J. (2004) Intake and discharge nutrient loads at three intensive shrimp farms. Aquaculture Research 35, 1053-1061.

Koroleff, F. (1976) Determination of ammonia. In: methods in seawater analysis (ed. by K. Grasshof K.), pp. 126-133. Verlag chemie, Weineim, RFA.

Lawrence A.L., Castille F., Velasco M. \& Samocha T. (2001). “Environmentally friendly”or "least polluting"' feed management program for shrimp farming. In: The NewWave. Proceedings of the Special Session on Sustainable Shrimp Culture (ed. by C.L. Browdy \& D.E. Jory), pp. 84-91.World Aquaculture Society, Baton Rouge, LA, USA.

Lemonnier H., Herlin J. (1999) A case of friendly shrimp aquaculture. In: Proceedings of the 1999 Annual meeting of the World Aquaculture Society Bridging the gap, Sydney, Australia, 26 april - 2 may 1999. World Aquaculture Society, Baton Rouge, Louisiana, USA.

Lemonnier H., Martin J.L.M., Brizard R. \& Herlin,J. (2003) Effect of water exchange rate on waste production in semi intensive shrimp ponds during the cold season in New Caledonia. Journal of the World Aquaculture Society 34(1), 40-49.

Lorenzen K, Struve J. \& Cowan V.J. (1997) Impact of farming intensity and water management on nitrogen dynamics in intensive pond culture: a mathematical model applied to Thai commercial shrimp farms. Aquaculture Research 48, 493-50.

Martin J.L.M., Veran Y., Guelorget O. \& Pham D. (1998) Shrimp rearing: stocking density, growth, impact on sediment, waste output; their relationships studied through the nitrogen budget in rearing ponds. Aquaculture 164, 135-149.

Martinez-Cordova L.R., Porchas-Cornejo M. A., Villarreal-Colmenares H. \& Calderon-Perez J. A. (1998) Winter culture of yellowleg shrimp Penaeus californiensis in aerated ponds with low water exchange. Journal of the World Aquaculture Society, 29(1), 120-124.

Paez-Osuna F., Guerrero-Galvan S.R., Ruiz-Fernandez A.C. \& Espinaza-Angulo R. (1997) Fluxes and mass balances of nutrients in a semi-intensive shrimp farm in North-Western Mexico. Marine Pollution Bulletin 34, 290-297.

Raimbault P., Pouvesle W., Diaz F., Garcia N. \& Sempéré R. (1999) Wet-oxidation and automated colorimetry for simultaneous determination of organic carbon, nitrogen and phosphorus dissolved in seawater. Marine Chemistry 66: 161-169

Sandifer P. A. \& Hopkins J.S. (1996) Conceptual design of a sustainable pond-based shrimp culture system. Aquacultural Engineering 15(1), 41-52.

Scherrer, B. (1984) Comparaison de deux échantillons appariés, le test des signes. In: Biostatistique (ed. by Gaëtan Morin ltée), pp. 523-528. Montréal, Canada.

Thakur D.P. \& Lin C.K. (2003) Water quality and nutrient budget in closed shrimp (Penaeus monodon) culture systems. Aquacultural Engineering 27, 159-176.

Teichert-Coddington D.R., Martinez D. \& Ramirez E. (2000) Partial nutrient budgets for semiintensive shrimp farms in Honduras. Aquaculture 190, 139- 154.

Wahab M.A., Bergheim A. \& Braaten B. (2003) Water quality and partial mass budget in extensive shrimp ponds in Bangladesh. Aquaculture 218, 413-423.

Wood E.D., Armstrong F.A.J. \& Richards F.A. (1967) Determination of nitrate in sea water by cadmium copper reduction to nitrite. Journal of the marine biological association of the United Kingdom 47, 23-31.

Wudtisin W. \& Boyd C.E. (2005) Determination of the phosphorus fertilization rate for bluegill ponds using regression analysis. Aquaculture Research 36: 593-599.

Ziemann D.A., Walsh W.A., Saphore E.G. \& Fulton-Bennet K. (1992) A survey of water quality characteristics of effluent from Hawaiian aquaculture facilities. Journal of the World Aquaculture Society 23, 180-191. 


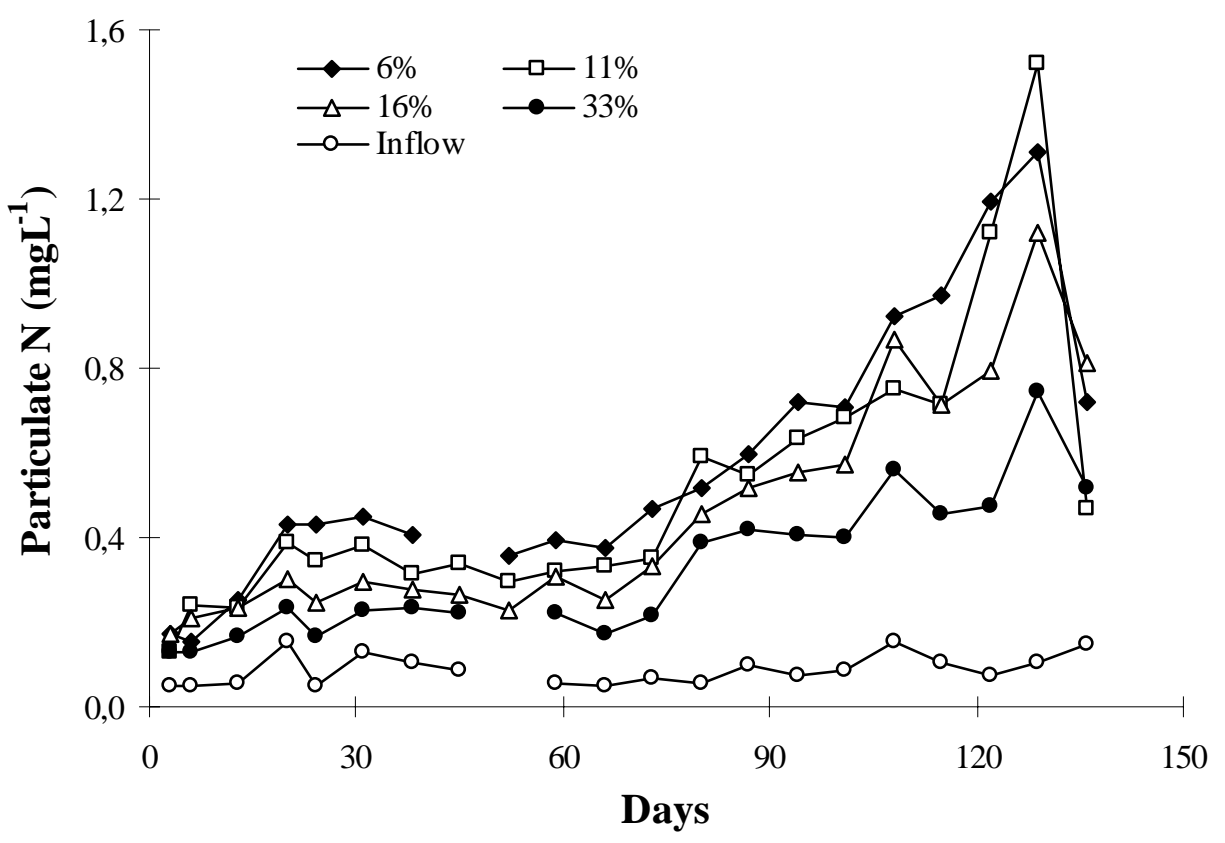

Figure 1 Variations of the concentrations of particulate nitrogen in the outflow of 4 ponds and in the inflow during the rearing cycle. 


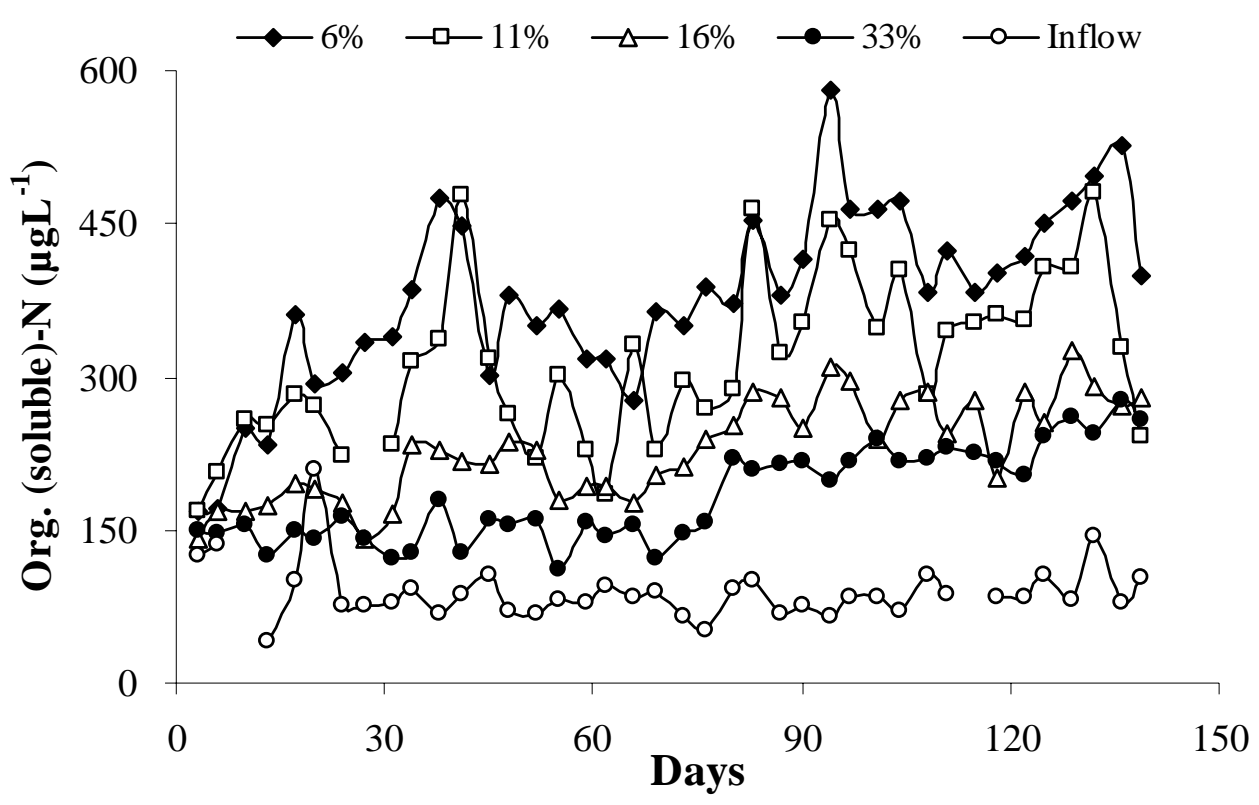

Figure 2 Variations of the concentrations of organic soluble nitrogen in the outflow of 4 ponds and in the inflow during the rearing cycle. 


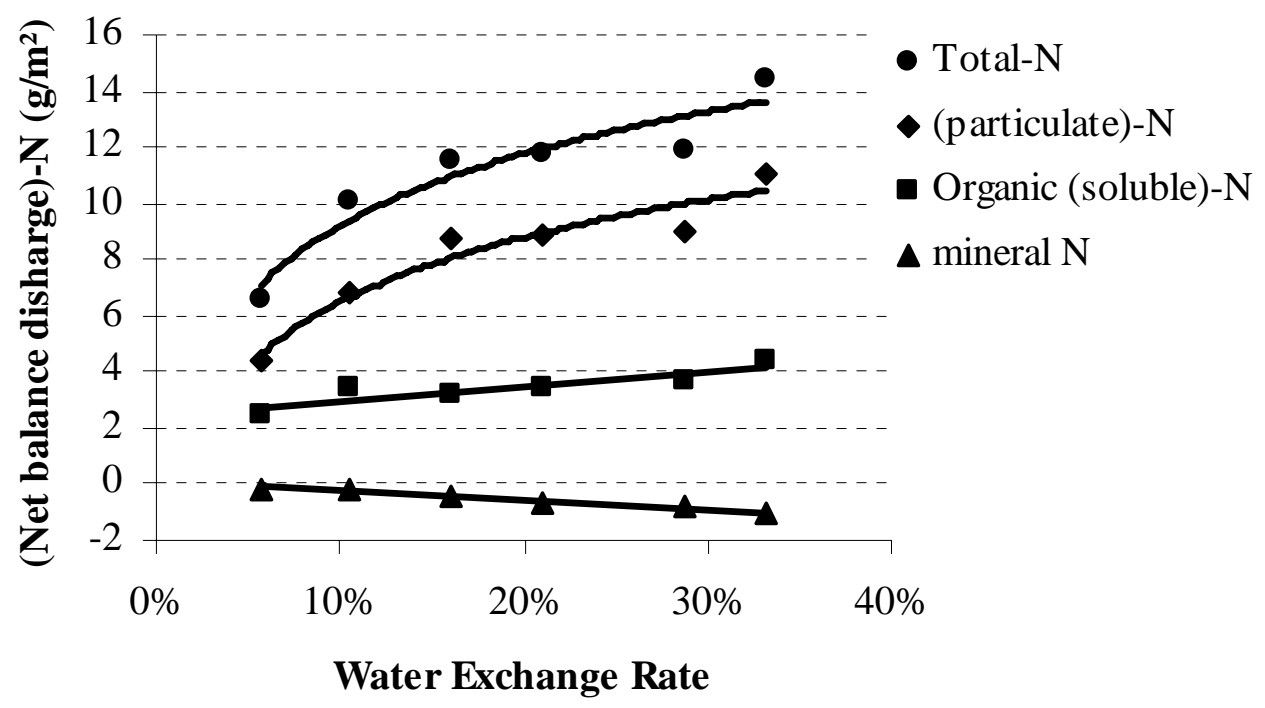

Figure 3 Relationships between nitrogen net balance discharge and water exchange rate. 
Table 1 Stocking and harvest data for six ponds stocked with Litopenaeus stylirostris at $20 \mathrm{~m}^{-2}$ with increasing levels of water exchange

\begin{tabular}{|c|c|c|c|c|c|c|}
\hline $\begin{array}{l}\text { Mean water exchange rate } \\
\left(\% \text { day }^{-1}\right)\end{array}$ & 6 & 11 & 16 & 21 & 29 & 33 \\
\hline Final density (shrimps $\mathrm{m}^{-2}$ ) & 15.6 & 15.5 & 16.2 & 15.3 & 15.6 & 14.3 \\
\hline Final biomass $\left(\mathrm{g} \mathrm{m}^{-2}\right)$ & 262 & 264 & 268 & 281 & 272 & 262 \\
\hline Final mean weight $g$ * & $16.8 \pm 1.7$ & $17.0 \pm 2.4$ & $16.6 \pm 1.7$ & $18.4 \pm 2.0$ & $18.6 \pm 1.7$ & $18.4 \pm 1.6$ \\
\hline Shrimp growth (g day ${ }^{-1}$ ) & 0.14 & 0.14 & 0.14 & 0.15 & 0.16 & 0.15 \\
\hline Survival rate (\%) & 78 & 77 & 81 & 76 & 73 & 71 \\
\hline Total Feed in pond $\left(\mathrm{g} \mathrm{m}^{-2}\right)$ & 592 & 589 & 581 & 625 & 621 & 604 \\
\hline $\mathrm{FCR}^{2}$ & 2.3 & 2.2 & 2.2 & 2.2 & 2.3 & 2.3 \\
\hline Production $\left(\mathrm{t} \mathrm{ha}^{-1} \mathrm{yr}^{-1}\right)$ & 6.7 & 6.7 & 6.9 & 7.2 & 6.9 & 6.7 \\
\hline
\end{tabular}

${ }^{*}$ Mean of 130 shrimps \pm SD

FCR, Feed conversion ratio 
Table 2 Means \pm SD and range of hydrobiological parameters in six ponds stocked at $20 . \mathrm{m}^{-2}$ with increasing levels of water exchange

\begin{tabular}{|c|c|c|c|c|c|c|}
\hline $\begin{array}{l}\text { Mean water exchange rate } \\
\left(\% \text { day }^{-1}\right)\end{array}$ & 6 & 11 & 16 & 21 & 29 & 33 \\
\hline 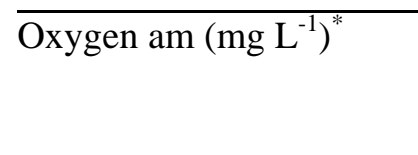 & $\begin{array}{l}5.8 \pm 1.4 \\
(1.5-8.8)\end{array}$ & $\begin{array}{l}5.8 \pm 1.5 \\
(1.3-8.5)\end{array}$ & $\begin{array}{l}5.9 \pm 1.3 \\
(1.0-9.1)\end{array}$ & $\begin{array}{l}5.9 \pm 1.3 \\
(1.2-8.3)\end{array}$ & $\begin{array}{l}6.0 \pm 1.2 \\
(2.5-8.3)\end{array}$ & $\begin{array}{l}6.0 \pm 1.3 \\
(1.8-8.2)\end{array}$ \\
\hline Oxygen pm (mg L $\left.{ }^{-1}\right)^{\#}$ & $\begin{array}{l}8.9 \pm 1.0 \\
(7.0-11.1)\end{array}$ & $\begin{array}{l}8.8 \pm 1.1 \\
(5.9-11.2)\end{array}$ & $\begin{array}{l}8.5 \pm 0.8 \\
(6.8-10.8)\end{array}$ & $\begin{array}{l}8.5 \pm 0.8 \\
(6.7-10.5)\end{array}$ & $\begin{array}{l}8.2 \pm 0.7 \\
(7.1-9.5)\end{array}$ & $\begin{array}{l}8.3 \pm 0.9 \\
(6.9-11.2)\end{array}$ \\
\hline pH am* & $\begin{array}{l}8.59 \pm 0.28 \\
(7.64-8.89)\end{array}$ & $\begin{array}{l}8.47 \pm 0.29 \\
(7.53-8.80)\end{array}$ & $\begin{array}{l}8.32 \pm 0.20 \\
(7.86-8.61)\end{array}$ & $\begin{array}{l}8.30 \pm 0.20 \\
(7.79-8.53)\end{array}$ & $\begin{array}{c}8.22 \pm 0.21 \\
(7.59-8.44)\end{array}$ & $\begin{array}{r}8.26 \pm 0.18 \\
(7.81-8.51)\end{array}$ \\
\hline pH pm ${ }^{\#}$ & $\begin{array}{l}8.71 \pm 0.20 \\
(7.97-9.02)\end{array}$ & $\begin{array}{l}8.60 \pm 0.19 \\
(7.92-8.83)\end{array}$ & $\begin{array}{l}8.46 \pm 0.14 \\
(7.97-8.66)\end{array}$ & $\begin{array}{l}8.43 \pm 0.12 \\
(8.12-8.66)\end{array}$ & $\begin{array}{l}8.33 \pm 0.15 \\
(7.88-8.57)\end{array}$ & $\begin{array}{l}8.38 \pm 0.10 \\
(8.15-8.64)\end{array}$ \\
\hline Salinity \%o ${ }^{*}$ & $\begin{array}{l}33.1 \pm 4.0 \\
(23-39.5)\end{array}$ & $\begin{array}{l}32.9 \pm 3.6 \\
(23-38.5)\end{array}$ & $\begin{array}{l}32.7 \pm 3.5 \\
(23-38)\end{array}$ & $\begin{array}{l}32.7 \pm 3.5 \\
(23-37.5)\end{array}$ & $\begin{array}{l}32.6 \pm 3.5 \\
(23-37)\end{array}$ & $\begin{array}{l}32.5 \pm 3.7 \\
(22-37)\end{array}$ \\
\hline $\begin{array}{l}\text { Secchi disk visibility } \\
\text { (cm) }\end{array}$ & $\begin{array}{l}43 \pm 22 \\
(15-120)\end{array}$ & $\begin{array}{l}44 \pm 22 \\
(15-115)\end{array}$ & $\begin{array}{l}47 \pm 22 \\
(15-110)\end{array}$ & $\begin{array}{l}52 \pm 25 \\
(20-120)\end{array}$ & $\begin{array}{c}58 \pm 24 \\
(15-120)\end{array}$ & $\begin{array}{l}61 \pm 27 \\
(20-130)\end{array}$ \\
\hline
\end{tabular}

${ }^{*}$ Each value represents the mean of 198 analyses

\# Each value represents the mean of 58 analyses 
Table 3 Means \pm SD and range for chemical and biological outflow water quality parameters for six ponds stocked at $20 . \mathrm{m}^{-2}$ with increasing levels of water exchange

\begin{tabular}{|c|c|c|c|c|c|c|c|}
\hline & \multirow[t]{2}{*}{ Inflow } & \multicolumn{6}{|c|}{ Outflow } \\
\hline $\begin{array}{l}\text { Mean water exchange } \\
\text { rate }\left(\% \text { day }^{-1}\right)\end{array}$ & & 6 & 11 & 16 & 21 & 29 & 33 \\
\hline \multicolumn{8}{|l|}{ Particulate } \\
\hline \multirow[t]{2}{*}{ Seston (mg L ${ }^{-1}$ ) } & $13.2 \pm 12.5$ & $20.5 \pm 10.7$ & $21.2 \pm 12.9$ & $22.2 \pm 14.2$ & $20.1 \pm 12.3$ & $23.1 \pm 20.9$ & $19.6 \pm 15.2$ \\
\hline & $(4.4-63.0)$ & $(4.0-49.0)$ & $(4.0-56.5)$ & $(5.8-56.0)$ & (3.6-55.5) & $(3.6-94.0)$ & $(4.4-68.0)$ \\
\hline \multirow[t]{2}{*}{ Org. Mat. (mg L L ${ }^{-1}$ ) } & $2.7 \pm 2.1$ & $10.8 \pm 6.0$ & $9.2 \pm 5.0$ & $7.8 \pm 3.8$ & $6.5 \pm 2.9$ & $5.4 \pm 3.0$ & $5.3 \pm 2.4$ \\
\hline & $(1.0-11.5)$ & $(1.7-28.0)$ & $(2.0-23.2)$ & $(2.6-17.0)$ & $(1.4-12.4)$ & $(1.2-15.2)$ & $(1.4-11.6)$ \\
\hline Mineral Mat. & $10.5 \pm 10.5$ & $9.8 \pm 7.2$ & $12.0 \pm 10.1$ & $14.5 \pm 11.0$ & $13.7 \pm 9.9$ & $17.7 \pm 18.2$ & $14.3 \pm 13.1$ \\
\hline$\left(\mathrm{mg} \mathrm{L}^{-1}\right)$ & $(2.5-51.5)$ & $(1.0-38.5)$ & $(1.8-47.0)$ & $(3.0-44.0)$ & $(1.8-46.5)$ & $(2.4-78.8)$ & $(2.4-58.0)$ \\
\hline \multirow[t]{2}{*}{ Chl $a\left(\mu \mathrm{g} \mathrm{L}^{-1}\right)$} & $1.9 \pm 1.1$ & $30.2 \pm 32.6$ & $27.1 \pm 30.2$ & $22.0 \pm 21.1$ & $19.9 \pm 21.2$ & $15.1 \pm 15.5$ & $15.1 \pm 15.9$ \\
\hline & $(0.8-4.5)$ & $(0.4-132.7)$ & $(2.6-138.1)$ & $(2.7-72.5)$ & $(2.7-78.9)$ & $(1.4-59.9)$ & $(2.3-56.1)$ \\
\hline \multirow[t]{2}{*}{$\mathrm{N}\left(\mu \mathrm{g} \mathrm{L^{-1 }}\right)$} & $87 \pm 36$ & $578 \pm 319$ & $510 \pm 453$ & $453 \pm 267$ & $379 \pm 209$ & $310 \pm 148$ & $324 \pm 169$ \\
\hline & $(48-153)$ & (155-1313) & $(129-1522)$ & $(173-1121)$ & $(135-870)$ & $(149-643)$ & $(127-742)$ \\
\hline \multirow[t]{2}{*}{$\mathrm{C} / \mathrm{N}$} & $6.4 \pm 2.8$ & $7.1 \pm 0.9$ & $7.1 \pm 0.7$ & $6.8 \pm 0.6$ & $6.6 \pm 0.7$ & $6.5 \pm 1.0$ & $6.2 \pm 0.7$ \\
\hline & $(2.6-13.0)$ & (5.6-8.5) & (5.9-8.5) & $(5.6-7.8)$ & (5.1-7.9) & (5.1-8.9) & $(4.8-7.2)$ \\
\hline
\end{tabular}

Each value represents the mean of 40 analyses except for particulate nitrogen and C/N (N=20). 
Table 3 next

Inflow

Outflow

Mean water exchange

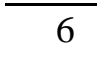

6

16

21

29

33 rate $\left(\%\right.$ day $\left.^{-1}\right)$

\begin{tabular}{|c|c|c|c|c|c|c|c|}
\hline Soluble & & & & & & & \\
\hline \multirow[t]{2}{*}{ TAN $\left(\mu g \mathrm{~L}^{-1}\right)$} & $19.5 \pm 11.6$ & $7.1 \pm 4.9$ & $20.7 \pm 66.2$ & $8.4 \pm 10.0$ & $7.1 \pm 6.9$ & $8.7 \pm 9.2$ & $6.0 \pm 5.3$ \\
\hline & $(7.0-59.1)$ & $(1.1-19.7)$ & $(2.0-367.9)$ & $(0.8-54.5)$ & $(1.0-35.6)$ & $(1.1-40.9)$ & $(1.3-23.0$ \\
\hline \multirow[t]{2}{*}{$\left(\mathrm{NO}_{2+3}{ }^{-}\right)-\mathrm{N}\left(\mu \mathrm{g} \mathrm{L}^{-1}\right)$} & $10.11 \pm 9.57$ & $0.48 \pm 0.26$ & $1.13 \pm 3.02$ & $0.37 \pm 0.25$ & $0.41 \pm 0.35$ & $0.43 \pm 0.33$ & $0.58 \pm 0.49$ \\
\hline & $(0.39-47.60)$ & $(0.14-1.15)$ & $(0.00-18.65)$ & $(0.00-1.32)$ & $(0.00-1.90)$ & $(0.00-1.64)$ & $(0.10-2.39)$ \\
\hline Organic (soluble)-N & $89 \pm 28$ & $378 \pm 89$ & $315 \pm 82$ & $229 \pm 49$ & $203 \pm 46$ & $181 \pm 31$ & $183 \pm 46$ \\
\hline$\left(\mu g \mathrm{~L}^{-1}\right)$ & $(42-208)$ & $(168-580)$ & (169-479) & $(140-326)$ & $(111-305)$ & $(119-240)$ & $(110-278)$ \\
\hline
\end{tabular}

Each value represents the mean of 40 analyses except for particulate nitrogen and $\mathrm{C} / \mathrm{N}(\underline{\mathrm{N}}=20)$. 
Table 4 Comparison between inflowing and outflowing water quality for each pond, and outflowing waters between all ponds using a distribution - free statistics named sign test

\begin{tabular}{|c|c|c|c|c|c|c|c|c|c|c|c|}
\hline & $\mathrm{pH}$ & $S \%$ & seston & $\begin{array}{c}\text { Particulate } \\
\text { organic matter }\end{array}$ & $\begin{array}{c}\text { Particulate } \\
\text { nitrogen }\end{array}$ & $\mathrm{C} / \mathrm{N}$ & Chl-a & $\begin{array}{c}\text { Mineral } \\
\text { matter }\end{array}$ & $\begin{array}{c}\text { Organic } \\
\text { (soluble)-N }\end{array}$ & TAN & $\mathrm{N}-\mathrm{NO}_{2,3}{ }^{-}$ \\
\hline $6 \%-11 \%$ & $* *$ & ns & ns & $* *$ & $* *$ & ns & $*$ & $*$ & $* *$ & ns & ns \\
\hline $6 \%-16 \%$ & $* *$ & ns & ns & $* *$ & $* *$ & ns & $* *$ & $* *$ & $* *$ & ns & ns \\
\hline $6 \%-21 \%$ & $* *$ & ns & ns & $* *$ & $* *$ & $* *$ & $* *$ & $* *$ & $* *$ & ns & ns \\
\hline $6 \%-29 \%$ & $* *$ & ns & ns & $* *$ & $* *$ & $* *$ & $* *$ & $* *$ & $* *$ & ns & ns \\
\hline $6 \%-33 \%$ & $* *$ & $*$ & & $* *$ & $* *$ & $* *$ & $* *$ & ns & $* *$ & ns & $* *$ \\
\hline 6\%-inflow & $* *$ & $*$ & $* *$ & $* *$ & $* *$ & ns & $* *$ & ns & $* *$ & $* *$ & $* *$ \\
\hline $11 \%-16 \%$ & $* *$ & $*$ & $*$ & $* *$ & $* *$ & $*$ & $* *$ & $* *$ & $* *$ & ns & $* *$ \\
\hline $11 \%-21 \%$ & $* *$ & $* *$ & $\mathrm{~ns}$ & $* *$ & $* *$ & $* *$ & $* *$ & $* *$ & $* *$ & ns & ns \\
\hline $11 \%-29 \%$ & $* *$ & * & ns & $* *$ & $* *$ & $* *$ & $* *$ & $* *$ & $* *$ & ns & $\mathrm{ns}$ \\
\hline $11 \%-33 \%$ & $* *$ & $*$ & $*$ & $* *$ & $* *$ & $* *$ & $* *$ & ns & $* *$ & ns & ns \\
\hline 11\%-inflow & $* *$ & ns & $* *$ & $* *$ & $* *$ & ns & $* *$ & ns & $* *$ & $* *$ & $* *$ \\
\hline $16 \%-21 \%$ & ns & $* *$ & $* *$ & $* *$ & $* *$ & ns & $* *$ & ns & $* *$ & ns & ns \\
\hline $16 \%-29 \%$ & $* *$ & & $*$ & $* *$ & $* *$ & ns & $* *$ & ns & $* *$ & ns & ns \\
\hline $16 \%-33 \%$ & $* *$ & & & $* *$ & $* *$ & & $* *$ & $\mathrm{~ns}$ & $* *$ & $\mathrm{~ns}$ & $*$ \\
\hline 16\%-inflow & $* *$ & & & $* *$ & $* *$ & ns & $* *$ & $* *$ & $* *$ & $* *$ & $* *$ \\
\hline $21 \%-29 \%$ & $* *$ & & ns & $* *$ & $* *$ & ns & $*$ & $*$ & $* *$ & ns & ns \\
\hline $21 \%-33 \%$ & $* *$ & & $*$ & $* *$ & $* *$ & ns & $* *$ & ns & $* *$ & ns & ns \\
\hline 21\%-ER & $* *$ & & $* *$ & $* *$ & $* *$ & ns & $* *$ & $* *$ & $* *$ & $* *$ & $* *$ \\
\hline $29 \%-33 \%$ & $* *$ & & ns & ns & ns & ns & ns & $*$ & $* *$ & ns & ns \\
\hline 29\%-inflow & $* *$ & & $* *$ & $* *$ & $* *$ & ns & $* *$ & $* *$ & $* *$ & $* *$ & $* *$ \\
\hline 33\%-inflow & $* *$ & & $* *$ & $* *$ & $* *$ & ns & $* *$ & ns & $* *$ & $* *$ & $* *$ \\
\hline
\end{tabular}

**Difference is significant with $\mathrm{P}<1 \%$.

* Difference is significant with $\mathrm{P}<5 \%$.

NS, difference is not significant. 
Table 5 Difference of sediment characteristics between the end and the beginning of the rearing

\begin{tabular}{|c|c|c|c|c|c|c|}
\hline Water exchange rate $\left(\%\right.$ day $\left.^{-1}\right)$ & 6 & 11 & 16 & 21 & 29 & 33 \\
\hline Accumulated layer $(\mathrm{cm})$ & $+1.4 \pm 1.2$ & $-0.1 \pm 2.0$ & $0.1 \pm 0.2$ & $0.5 \pm 1.2$ & $0.1 \pm 1.4$ & $-0.2 \pm 0.9$ \\
\hline$\Delta$ Water content $(\%)$ & $+23 \pm 15$ & $+18 \pm 15$ & $+12 \pm 11$ & $+15 \pm 17$ & $+13 \pm 17$ & $+9 \pm 17$ \\
\hline$\Delta$ Redox $(\mathrm{mV})$ & $-60 \pm 44$ & $-46 \pm 60$ & $-31 \pm 44$ & $-24 \pm 64$ & $-3 \pm 61$ & $+34 \pm 28$ \\
\hline$\Delta \mathrm{pH}$ in situ & $+0.5 \pm 0.2$ & $+0.5 \pm 0.1$ & $+0.7 \pm 0.1$ & $+0.7 \pm 0.3$ & $+0.5 \pm 0.1$ & $+0.5 \pm 0.2$ \\
\hline$\Delta$ TAN $\left(\mathrm{mg} \mathrm{L}^{-1}\right)$ & $+5.1 \pm 2.1$ & $+4.9 \pm 3.9$ & $+3.8 \pm 2.7$ & $+4.1 \pm 5.9$ & $+2.2 \pm 0.9$ & $+0.8 \pm 1.7$ \\
\hline$\Delta\left(\mathrm{NO}_{2}^{-}+\mathrm{NO}_{3}^{-}\right)^{-}-\mathrm{N}\left(\mu \mathrm{g} \mathrm{L}^{-1}\right)$ & $-2.2 \pm 1.9$ & $-4.9 \pm 5.8$ & $-5.4 \pm 6.6$ & $-11.4 \pm 12.3$ & $-4.3 \pm 1.5$ & $-34.9 \pm 13.8$ \\
\hline$\Delta$ Total Nitrogen (mg g ${ }^{-1}$ dry weight) ${ }^{a}$ & $+1.00 \pm 0.73$ & $+0.76 \pm 1.00$ & $+0.47 \pm 0.47$ & $+0.38 \pm 0.52$ & $+0.68 \pm 0.96$ & $+0.21 \pm 0.41$ \\
\hline
\end{tabular}


Table 6 Nitrogen budget in the ponds

\begin{tabular}{|c|c|c|c|c|c|c|}
\hline Water exchange rate $\left(\%\right.$ day $\left.^{-1}\right)$ & 6 & 11 & 16 & 21 & 29 & 33 \\
\hline \multicolumn{7}{|l|}{ INPUT-N $\left(\mathrm{g} \mathrm{m}^{-2}\right)$} \\
\hline Water-N (dissolved + particulate) ${ }^{*}$ & $1.6(4)$ & $2.9(7)$ & $4.5(10)$ & $5.8(12)$ & $7.9(15)$ & $9.1(18)$ \\
\hline Feed pellets-N* & $41.1(96)$ & $40.9(93)$ & $40.4(90)$ & $43.4(88)$ & $43.2(85)$ & $42.0(82)$ \\
\hline Total input-N & 42.7 & 43.8 & 44.9 & 49.2 & 51.1 & 51.1 \\
\hline \multicolumn{7}{|l|}{ OUTPUT-N ( $\left.\mathrm{g} \mathrm{m}^{-2}\right)$} \\
\hline Water-N (dissolved + particulate) ${ }^{*}$ & $8.2(19)$ & $13.0(30)$ & $16.0(36)$ & $17.6(36)$ & $19.8(39)$ & $23.5(46)$ \\
\hline Shrimp-N* & $8.5(20)$ & $8.6(20)$ & $8.6(19)$ & $9.0(18)$ & $8.8(17)$ & $8.5(17)$ \\
\hline $\mathrm{N}$ in excess in sediment ${ }^{*}$ & $10.9(26)$ & $10.8(25)$ & $8.3(19)$ & $5.6(11)$ & $10.4(20)$ & 3.8 (7) \\
\hline Other ( $\mathrm{N}$ loss to atmosphere and seepage) ${ }^{*}$ & $15.2(36)$ & $11.5(26)$ & $11.9(26)$ & $17.1(35)$ & $12.1(24)$ & $15.3(30)$ \\
\hline
\end{tabular}

${ }^{*}$ In brackets is expressed the percentage of the compartment versus total input-N. 